\title{
Surface Patterning with Fluorescent Molecules Using Click Chemistry Directed by Scanning Electrochemical Microscopy (SECM)
}

\author{
Sung-Yu Ku, Ken-Tsung Wong, ${ }^{*}$ and Allen J. Bard* \\ Center for Electrochemistry, Department of Chemistry and Biochemistry, University of \\ Texas at Austin, Austin, Texas 78712, and Department of Chemistry, National Taiwan \\ University, Taipei 106, Taiwan
}

\section{Supporting Information}

\section{Contents}

Preparation of $\mathrm{Cu}$ (II) salen $\quad 1$

Synthesis of benzothiodiazole fluorophore 1

Photophysical properties of $\mathbf{1} 3$

Cyclic voltammogram of $\mathrm{Cu}(\mathrm{II})$ salen $\quad 4$

Preparation of azido-terminated SAMs on a glass substrate 4

Scanning electrochemical microscopy $\quad 5$

$\begin{array}{ll}\text { Calibration of distance between a tip and an insulating substrate } & 6\end{array}$

\section{Preparation of $\mathrm{Cu}(\mathrm{II})$ salen}

Copper (II) salen was prepared by adding one equivalent copper (II) acetate and one equivalent salen ligand in ethanol. The mixture was heated at $50{ }^{\circ} \mathrm{C}$ for one hour, and then cooled to room temperature. The product was isolated by filtration and washed with ethanol, and finally dried in oven.

\section{Synthetic pathway toward benzothiodiazole fluorophore (1)}

Scheme S-1 depicts our synthesis of acetylene-fluorophore. The Suzuki coupling reaction of dibromobenzothiodiazole with 4-methoxyphenylboronic acid in the presence of catalytic amount of $\mathrm{Pd}\left(\mathrm{PPh}_{3}\right)_{4}$ and $\mathrm{P}^{t} \mathrm{Bu}_{3}$ gave 2 in an isolated yield of $90 \%$ after purification through recrystallization. Subsequent selective mono-deprotection of $\mathbf{2}$ afforded modest yield $60 \%$ of $\mathbf{3}$ by means of excess amounts of $\mathrm{HBr}$ (33\% in HOAc). After purification of $\mathbf{3}$ with column chromatography, treatment of $\mathbf{5}$ with excess amounts of propagyl bromide, $\mathrm{K}_{2} \mathrm{CO}_{3}$ and a catalytic amount of $\mathrm{KI}(10 \mathrm{~mol} \%)$ in acetonitrile at $60{ }^{\circ} \mathrm{C}$ for $5 \mathrm{~h}$ led to the desired compound $\mathbf{1}$ in an isolated yield of $80 \%$ by recrystallization. 

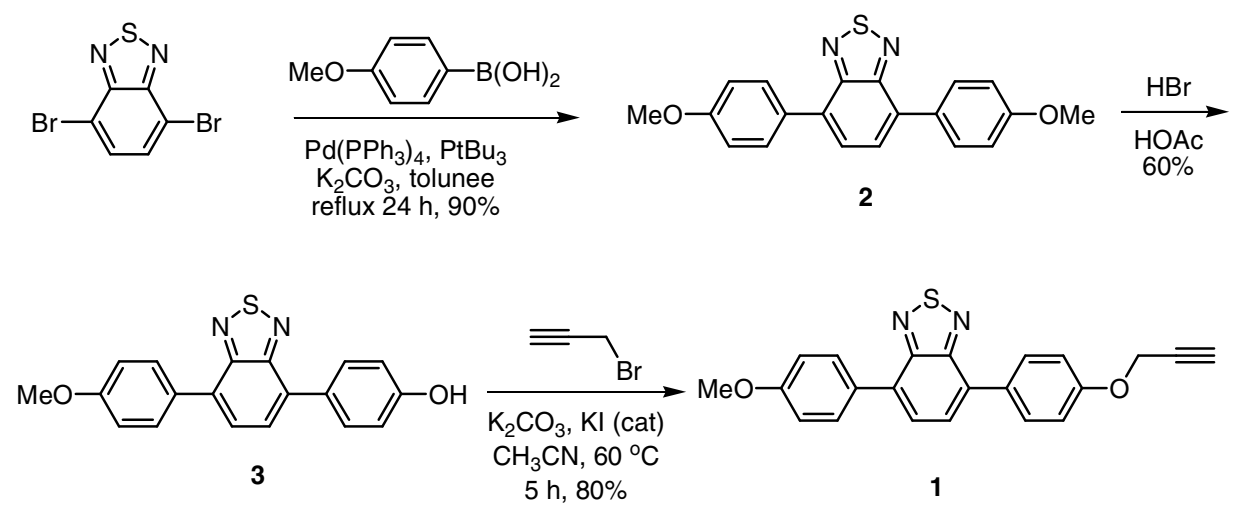

Scheme S- 1. Synthetic pathway toward benzothiodiazole-containing fluorophore 1.

\section{Synthetic procedures:}

Compound 2: Dibrombenzothidiazole (11.76 g, $40 \mathrm{mmol})$, 4-methoxyphenylboronic acid $(15.19 \mathrm{~g}, 100 \mathrm{mmol})$, and $\mathrm{Pd}\left(\mathrm{PPh}_{3}\right)_{4}(1.16 \mathrm{~g}, 1.0 \mathrm{mmol})$ were add to a $500 \mathrm{~mL}$ two-neck flask equipped with septum. The flask was evacuated and back filled with argon. Toluene (150 mL), $\mathrm{P}^{t} \mathrm{Bu}_{3}\left(20 \mathrm{~mL}, 1 \mathrm{mmol}, 0.05 \mathrm{M}\right.$ in toluene), and $\mathrm{K}_{2} \mathrm{CO}_{3}(2 \mathrm{M}$, $60 \mathrm{~mL}, 120 \mathrm{mmol}$ ) was added via a syringe at room temperature. The reaction mixture was heated at $110{ }^{\circ} \mathrm{C}$ for 24 hours and the precipitation appeared after cooled to room temperature. The precipitation was collected by filtration and washed with hot hexane. The organic solution was extracted with water and $\mathrm{CH}_{2} \mathrm{Cl}_{2}$ for three times and the organic solution was collected, dried with $\mathrm{MgSO}_{4}$ and evaporated with a rotary evaporator to give the crude product. Purification by recrystallization with $\mathrm{CH}_{2} \mathrm{Cl}_{2}$ / hexane afforded a 90\% yield of compound 2 (31.3 g). mp. 200 202 ${ }^{\circ} \mathrm{C} ;{ }^{1} \mathrm{H}$ NMR $\left(\mathrm{CDCl}_{3}, 400 \mathrm{MHz}\right) \delta 7.93(\mathrm{~d}, J=9.2 \mathrm{~Hz}, 4 \mathrm{H}), 7.72(\mathrm{~s}, 2 \mathrm{H}), 7.09(\mathrm{~d}, J=9.2 \mathrm{~Hz}, 4 \mathrm{H})$, $3.91(\mathrm{~s}, 6 \mathrm{H}) ;{ }^{13} \mathrm{C} \mathrm{NMR}\left(\mathrm{CDCl}_{3}, 100 \mathrm{MHz}\right) \delta 159.5,153.9,132.1,130.2 .129 .8,127.2$, 113.9, 55.4; HRMS (ESI) Cacld for $\mathrm{C}_{20} \mathrm{H}_{12} \mathrm{~N}_{2} \mathrm{O}_{2} \mathrm{~S} 348.0932$, found 348.0920.

Compound 3 : Compound 2 (348 $\mathrm{mg}, 1.0 \mathrm{mmol}$ ) and tetrabutylammonium bromide (322 mg, $1.0 \mathrm{mmol}$ ) were added to a $100 \mathrm{~mL}$ flask, and $\mathrm{HBr}$ (33\% in HOAc, $30 \mathrm{~mL}$ ) was added. The mixture was heated for 5 hours at $100{ }^{\circ} \mathrm{C}$, then cooled to room temperature, and $20 \mathrm{~mL}$ water was added. The mixture was extracted with $\mathrm{CH}_{2} \mathrm{Cl}_{2}$ /water, and then organic solution was neutralized with $\mathrm{NaOH}_{(a q)}$ and dilute $\mathrm{HCl}_{(a q)}$ in sequence. The organic solution was collected, dried with $\mathrm{MgSO}_{4}$ and evaporated with a rotary evaporator. Product was purified through chromatography on silica gel $($ EtOAc/ Hexane $=1 / 3)$ to give a $60 \%$ yield of compound $3(200 \mathrm{mg})$. mp. 264 265 ${ }^{\circ} \mathrm{C} ;{ }^{1} \mathrm{H}$ NMR (d ${ }^{6}$-acetone, $\left.400 \mathrm{MHz}\right) \delta 8.51(\mathrm{~s}, 1 \mathrm{H}), 7.87(\mathrm{~d}, J=8.8 \mathrm{~Hz}, 2 \mathrm{H})$, $7.80(\mathrm{~d}, J=8.8 \mathrm{~Hz}, 2 \mathrm{H}), 7.70(\mathrm{~d}, J=2.4 \mathrm{~Hz}, 2 \mathrm{H}), 6.96(\mathrm{~d}, J=8.8 \mathrm{~Hz}, 2 \mathrm{H}), 6.87(\mathrm{~d}, J=$ $8.8 \mathrm{~Hz}, 2 \mathrm{H}), 3.75(\mathrm{~s}, 3 \mathrm{H}) ;{ }^{13} \mathrm{C} \mathrm{NMR}\left(\mathrm{d}^{6}\right.$-acetone, $\left.100 \mathrm{MHz}\right) \delta 159.9,157.8,154.1$, 
131.9, 130.7, 130.6, 130.0, 128.9, 127.7, 127.4, 115.6, 114.1, 55.5; HRMS (ESI) Cacld for $\mathrm{C}_{19} \mathrm{H}_{14} \mathrm{~N}_{2} \mathrm{O}_{2} \mathrm{~S} 334.0776$, found 334.0705.

Compound 1 : Compound 3 (334 mg, $1.0 \mathrm{mmol}), \mathrm{K}_{2} \mathrm{CO}_{3}(276 \mathrm{mg}, 1.0 \mathrm{mmol})$, and KI (166 mg, $1.0 \mathrm{mmol})$ were added to a $100 \mathrm{~mL}$ flask. Then acetonitrile $(20 \mathrm{~mL})$ and propagyl bromide ( $2 \mathrm{mmol}, 170 u \mathrm{~L}$ ) were added into the mixture, which was heated for 5 hours at $50{ }^{\circ} \mathrm{C}$. The acetonirtrile was removed by a rotary evaporator. The mixture was extracted with ethyl acetate/water and and washed with dilute $\mathrm{HCl}$ in sequence. The organic solution was collected, dried over $\mathrm{MgSO}_{4}$ and evaporated. Purification by recrystallization with $\mathrm{CH}_{2} \mathrm{Cl}_{2} /$ hexane gave an $80 \%$ yield of compound 1 (297 mg). mp. 169 $171{ }^{\circ} \mathrm{C} ;{ }^{1} \mathrm{H}$ NMR $\left(\mathrm{CDCl}_{3}, 400 \mathrm{MHz}\right) \delta 7.95 \sim 7.91$ (m, 4H), 7.73 (s, 2H), 7.16 (d, $J$ $=8.8 \mathrm{~Hz}, 2 \mathrm{H}), 7.09(\mathrm{~d}, J=8.8 \mathrm{~Hz}, 2 \mathrm{H}), 4.79(\mathrm{~d}, J=2.4,2 \mathrm{H}), 3.91(\mathrm{~s}, 3 \mathrm{H}), 2.58(\mathrm{t}, J=$

2.4, 1H); ${ }^{13} \mathrm{C} \mathrm{NMR}\left(\mathrm{CDCl}_{3}, 100 \mathrm{MHz}\right) \delta 159.5,157.4,153.9,132.3,131.9,130.7$, $130.2,129.8,127.3,127.2,114.9,114.0,94.2,78.4,75.7,55.9,55.4$; HRMS (ESI) Cacld for $\mathrm{C}_{22} \mathrm{H}_{16} \mathrm{~N}_{2} \mathrm{O}_{2} \mathrm{~S} 372.0932$, found 372.0925.

\section{Photophysical Measurements}

Figure S-1 depicts the steady-state absorption and emission spectra of compound 1 $\left(2 \times 10^{-6} \mathrm{M}\right)$ in dichloromethane, which were recorded with a spectrophotometer and a fluorometer, respectively.

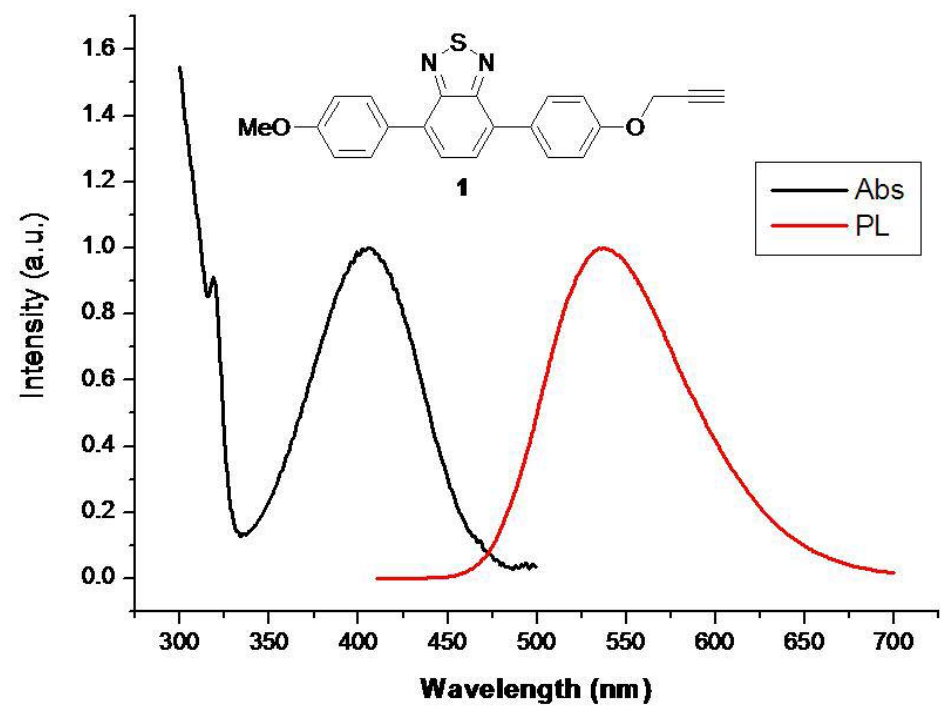

Figure S-1: Absorption and photoluminescence spectra of benzothiodiazolecontaining fluorophore $\mathbf{1}$ in dichloromethane.

\section{Cyclic voltammograms of $\mathrm{Cu}(\mathrm{II})$ salen}


We chose $\mathrm{Cu}$ (II) salen as the $\mathrm{Cu}$-source and DMF as solvent to achieve a stable $\mathrm{Cu}(\mathrm{I})$ species and solubility of the other reagents to allow the click reaction occur in the small gap between the gold UME and the glass substrate. Figure S-2 shows a typical cyclic voltammogram (CV) of $\mathrm{Cu}$ (II) salen at a gold microelectrode in DMF, which shows typical Nernstian behavior at $-1.0 \mathrm{~V}$ vs Ag QRE (quasi-reference electrode), indicating that $\mathrm{CVs}$ at a larger electrode demonstrate that a stable $\mathrm{Cu}(\mathrm{I})$ intermediate can be obtained.

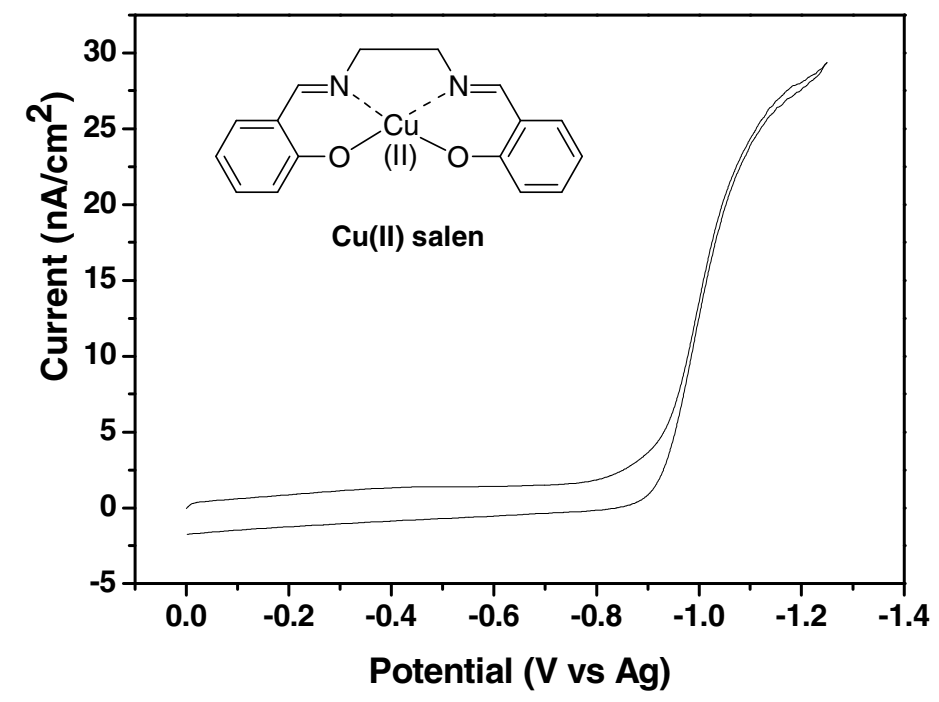

Figure S-2: Cyclic voltammograms of $3 \mathrm{mM}$ copper(II) salen at a $100 \mu \mathrm{m}$ (in diam.) gold electrode in DMF containing 0.1 M $n-\mathrm{Bu}_{4} \mathrm{NBF}_{4}$. Scan rate, $75 \mathrm{mV} / \mathrm{sec}$.

\section{Preparation of azido-terminated SAMs on a glass substrate ${ }^{1}$}

\section{Clean the glass slides:}

Detergent (Alconox, 10\%) was added into deionized water and the solution was heated to $80{ }^{\circ} \mathrm{C}$. The glass slides were immersed and sonicated for $10 \mathrm{~min}$, and rinsed with deionized water. $\mathrm{A} \mathrm{NaOH}(10 \%)$ aqueous solution was heated to $80{ }^{\circ} \mathrm{C}$ and the glass slides were immersed in this hot $\mathrm{NaOH}_{(a q)}$ for $5 \mathrm{~min}$, followed by rinsed with water and immersed for $2 \mathrm{~min}$ in a dilute solution of $\mathrm{HCl}(1 \%)$. The glass slides were sonicated in hot distilled water for $10 \mathrm{~min}$, finally rinsed with distilled water and dried in a stream of air.

\section{SAM formation of 4:}

${ }^{1}$ (a) Fryxell, G. E.; Rieke, P. C.; Wood, L. L.; Engelhard, M. H.; Williford, R. E.; Graff, G. L.; Champbell, A. A.; Wiacek, R. J.; Lee, L.; Halverson, A. Langmuir 1996, 12, 5064. (b) Balachander, N.; Sukenik, C. N. Langmuir 1990, 6, 1621. 
The clean glass slides were exposed to a $1.0 \%$ (volume /volume) solution of 11-bromoundecyltrichlorosilane in dry dichloromethane for one hour at room temperature. After exposure to the silane solution, the glass slides were cleaned with sonication for $5 \mathrm{~min}$ in freshly distilled dichloromethane to remove any excess residue of trichlorosilane. The glass slides were then sonicated for $5 \mathrm{~min}$ in ethanol and pure water, respectively. Finally, the glass slides were dried in a stream of air.

\section{In situ displacement of $\mathrm{Br}$ by $\mathrm{N}_{3}$ :}

The azido-terminated SAMs $\mathbf{5}$ on a glass substrate was prepared by the substitution of a bromo-terminated monolayer 4 with $\mathrm{NaN}_{3}$. The bromo-terminated SAM on a glass substrate was placed in a saturated solution of $\mathrm{NaN}_{3}$ in DMF, heated at $80{ }^{\circ} \mathrm{C}$ for 48 hours. The substrate was removed and rinsed with pure water.

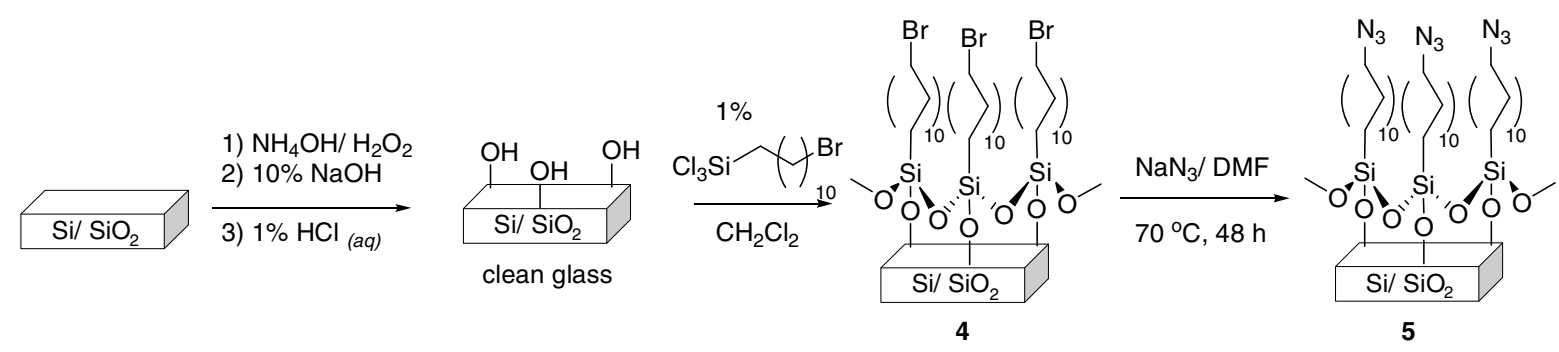

Scheme S-2. Synthetic pathway for preparing azido-terminated SAMs on a glass substrate

\section{Scanning Electrochemical Microscopy}

The SECM probe tips were constructed by heat-healing $100 \mu \mathrm{m}$ (diameter) gold wire in glass capillaries under vacuum, and followed by polishing and sharpening. ${ }^{2}$ The bottom cross section of the Au tip was polished with sandpaper until the metal disk was exposed. The tip was the polished with alumina $(0.3 \mu \mathrm{m})$ and sharpened until RG 2 was obtained. SECM measurements were performed by using a PC-controlled CHI model 900SECM (CHI Instruments, Austin, TX) to control the X-Y-Z displacement. A Ag wire and a Au wire were used as quasi reference and auxiliary electrodes, respectively. The SECM cell was carefully designed to reduce the sample tilt. The Teflon cell with a $6.5 \mathrm{~mm}$ diameter aperture containing an O-ring was then placed on top of the glass substrate with SAMs and tightened using two connecting screws. Thus, the cells were exposed to the solution of ferrocene and $n-\mathrm{Bu}_{4} \mathrm{NBF}_{4}$ in DMF. This cell was mounted on top of the regular SECM instrument stage. It was

\footnotetext{
${ }^{2}$ Bard, A. J. Scanning Electrochemical Microscopy; Bard, A. J., Mirkin, M. V., Eds.; Marcel Dekker: New York, 2001.
} 
verified by SECM feedback scans with ferrocene that the tilt of this setup was $z / x$ (or $y$ ) $\quad 1.5 \mu \mathrm{m} / \mathrm{mm}$. The SECM tip was translated toward the substrate surface using conventional feedback mode SECM, employing the ferrocene oxidation reaction at the SECM tip to monitor the approach of the tip to the glass substrate surface through negative feedback. Using the feedback approach curve, the tip-substrate distance was set at $28 \mu \mathrm{m}$, where tip current decreases $50 \%$ of the steady state current at far distance. The solution in the SECM cell was removed by a pipet and the cell was cleaned with DMF for 3 times. The mixture of $\mathrm{Cu}(\mathrm{II})$ salen $(2.6 \mathrm{mM}), \mathbf{1}(0.6 \mathrm{mM})$ and $n-\mathrm{Bu}_{4} \mathrm{NBF}_{4}$ $(100 \mathrm{mM})$ in DMF was added into the cell, and the solution was deoxygenated using argon for $10 \mathrm{~min}$ before performing electrolysis. A blanket of argon was maintained over the solution at all times during the experiment to avoid interference from atmospheric oxygen. The SECM tip, held the $28 \mu \mathrm{m}$ from the glass substrate, was applied at $-1.08 \mathrm{~V}$ for $20 \mathrm{~min}$, while electrogenerating $\mathrm{Cu}(\mathrm{I})$ species to catalyze the reaction chemistry. After applying $-1.08 \mathrm{~V}$ for $20 \mathrm{~min}$, the tip was moved to $700 \mu \mathrm{m}$ (x axial or $y$ axial) and the solution was deoxygenated using argon for $3 \mathrm{~min}$. Then the same electrolysis procedure was repeated for 4 times. After electrolysis, the glass substrate was cleaned with acetone and ethanol for 3 times, and dried with a stream of air.

\section{Calibration of distance between a tip and an insulating substrate ${ }^{1}$}

Using the feedback approach curve, the tip-substrate distance was set at specific height $d_{f} \mu \mathrm{m}$, where tip current decreases $50 \%$ of the steady state current at far distance. $\mathrm{d}_{\mathrm{f}} \mu \mathrm{m}$ can be fitted as $28 \mu \mathrm{m}$ through theoretical calibration by the equation 1 for insulating substrate.

$50 \mu \mathrm{m}$ gold electrode (radius)

$\mathrm{RG}=2$

$\mathrm{L}=\mathrm{d} / \mathrm{a}$

$\left.\mathrm{I}_{\text {Theory }}=1 /[\mathrm{A}+\mathrm{B} / \mathrm{L}+\mathrm{C} \exp (\mathrm{D} / \mathrm{L})]+\mathrm{E}^{*} \mathrm{~L} /(\mathrm{F}+\mathrm{L})\right]$

Max increase $=0.25 \mu \mathrm{m} / \mathrm{s}$ 


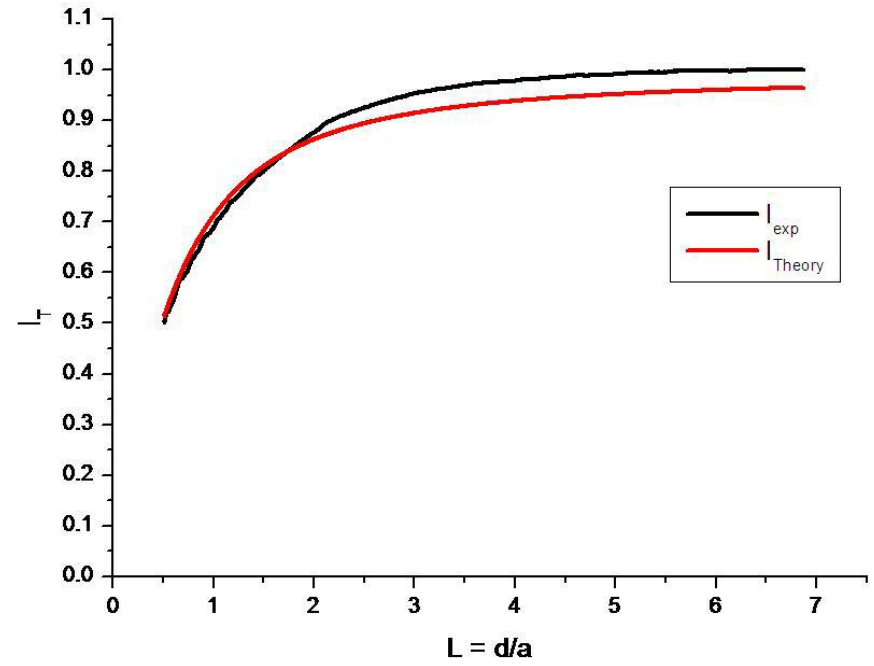

Figure S-3. Insulating approach curve of azido-terminated SAMs 